\title{
KOMUNIKASI TERAPEUTIK \\ DALAM PEMULIHAN KOMPETENSI LINGUISTIK PASIEN PENYANDANG AFASIA BROCA
}

\author{
Riki Nasrullah $^{1}$, Dadang Suganda ${ }^{2}$, Wagiati $^{3}$, Sugeng Riyanto ${ }^{4}$ \\ Fakultas Ilmu Budaya Universitas Padjadjaran \\ Surel: rikinasrullah5@gmail.com ${ }^{1}$ \\ dadang.suganda@unpad.ac.id ${ }^{2}$ \\ wagiati@unpad.ac.id ${ }^{3}$ \\ sugeng.riyanto@unpad.ac.id ${ }^{4}$
}

\begin{abstract}
Abstrak
Penelitian ini berjudul "Komunikasi Terapeutik dalam Pemulihan Kompetensi Linguistik Pasien Penyandang Afasia Broca"; bertujuan menjelaskan pola-pola komunikasi terapeutik antara terapis dengan pasien penyandang afasia broca di Rumah Sakit Pusat Otak Nasional Jakarta. Penelitian ini dilakukan dengan menggunakan metode kualitatif-deskriptif dengan pendekatan studi kasus. Data penelitian ini berupa ekspresi verbal para penyandang afasia broca berbahasa Indonesia dan dari proses berlangsungnya terapi wicara antara terapis wicara dengan penyandang afasia. Secara keseluruhan penelitian ini mengambil lokasi di Rumah Sakit Pusat Otak Nasional. Sebanyak 3 (tiga) orang responden dijadikan sampel penelitian yang memenuhi kriteria inklusi. Penyandang afasia broca memiliki problematika lingual yang begitu memperihatikan. Mereka memiliki masalah dalam mengungkapkan pikirannya melalui bahasa. Komunikasi terapeutik antara pasien dan terapis juga menjadi hal yang menarik untuk dikaji.Hasil penelitian menunjukkan bahwa (1) penyandang afasia broca memiliki problematika lingual yang begitu memperihatikan, yakni mereka memiliki masalah dalam mengungkapkan pikirannya melalui bahasa; (2) dari proses komunikasi terapeutik yang ada di Rumah Sakit Pusat Otak Nasional antara terapis wicara dengan klien penyandang afasia broca, terdapat beberapa gejala lingual yakni adanya alih gaya (style shifting)) dan adanya pemberian feedback positif dari terapis wicara kepada klien penyandang afasia broca. Jurnal limiah
\end{abstract}

Kata Kunci: komunikasi terapeutik, kompetensílinguistik, afasia broca.

\begin{abstract}
This study aims to explain the therapeutic communication patterns between therapists and patients with broca aphasia at the Jakarta National Brain Center Hospital (RSPON). This research was conducted using qualitative-descriptive methods with a case study approach. The research data were in the forms of verbal expressions of patients with broca aphasia speakers in Indonesia and from the process of ongoing speech therapy between speech therapists with aphasia speaker.
\end{abstract}


Overall, the research was conducted at the National Brain Center Hospital. Three (3) respondents were involved as the research subjects that met the inclusion criteria. The results showed that (1) people with Broca Aphasia are fluent in lingual problems that are so alarming, they have problems expressing their thoughts in language; (2) from the therapeutic communication process at the National Brain Center Hospital between speech therapists and Broca aphasia clients, there are several lingual symptoms, are the style shifting and giving positive feedback from speech therapists to broca aphasia clients.

Keywords: therapeutic communication, linguistic competence, broca aphasia.

\section{PENDAHULUAN}

Linguistik dipahami sebagai suatu kajian ilmiah yang menjadikan bahasa sebagai objek kajiannya. Linguistik menjadi satu di antara cabang ilmu yang memiliki sifat empiris. Disebut empiris karena data yang dibahas dan dianalisis oleh linguistik adalah suatu fakta lingual yang dapat diamati di lapangan dan kebenarannya dapat diverifikasi. Empirisme bahasa yang dijadikan objek dalam linguistik itu didapat dari hasil analisis deskriptif fenomenafenomena lingual yang terjadi pada penutur suatu bahasa tertentu. Bahasa yang dimaksudkan adalah bahasa yang diujarkan manusia yang memiliki sifat alamiah dan apa adanya, tidak dibuat-buat untuk memenuhi fungsi-fungsi sosial penuturnya.

Dalam ranah personal Judan individual, bahasa menjadi fungsi inti bagi manusia dalam kaitannya dengan komunikasi, selain fungsi daya mengingat, persepsi, kognisi, dan emosi. Kerusakan yang terjadi pada bagian-bagian otak manusia akan menimbulkan gangguan pada kemampuan berbahasa seseorang. Ada setidaknya empat kerusakan pada bagian otak yang menimbulkan gangguan pada kemampuan bahasa seseorang, yaitu afasia, agnosia, apraksia, dan disartria (Sastra, 2011:42).

AIA (2011) telah menyebutkan bahwa para penyandang afasia akan mengalami kesulitan dalam banyak hal. Hal-hal yang dimaksud merupakan sesuatu yang biasa terjadi di kehidupannya sehari-hari, khususnya dalam hal komunikasi, seperti melakukan percakapan; berbicara dalam grup atau lingkungan yang gaduh; membaca buku, koran, majalah atau papan petunjuk di jalan raya; pemahaman akan lelucon atau menceritakan lelucon; mengikuti program di televisi atau radio; menulis surat atau mengisi formulir, bertelepon, berhitung, mengingat angka, atau berurusan dengan uang; juga menyebutkan namanya sendiri atau nama-nama anggota keluarga. Penyandang afasia mengalami kesulitan dalam menggunakan bahasa, fetapi mereka bukanlah orang yang tidak waras.

Dalam hubungannya dengan kompetensi berbahasa, afasia dipahami sebagai gejala atau gangguan yang terjadi pada kemampuan berbahasa seseorang yang diakibatkan oleh kerusakan pada korteks (Sastra, 2011:42). Afasia tidak terjadi pada seseorang yang sebelumnya tidak memiliki sistem bahasa tertentu. Maksudnya adalah afasia hanya akan 
terjadi pada seseorang yang sebelumnya sudah memiliki sistem bahasa tertentu. Senada dengan apa yang diungkapkan Sastra, Kusmoputro (1999:22) juga menyatakan bahwa afasia sebagai salah satu gangguan kebahasaan seseorang (baik lisan maupun tulis) yang disebabkan oleh gangguan atau kerusakan pada bagian otak. Dari kedua definisi di atas, jelaslah bahwa afasia merupakan gejala patologi bahasa pada diri seseorang yang diakibatkan oleh adanya kerusakan pada satu di antara bagian-bagian otak. Kerusakan otak itu sendiri dapat disebabkan oleh berbagai macam penyakit, tetapi yang paling sering diakibatkan oleh penyakit gangguan peredaran darah di otak dan cedera otak (strok dan trauma) (Yunus, 1999:3).

Dalam hubungannya dengan ranah psikologis, para penyandang afasia kerap memandang dirinya berbeda dengan orang lain di sekitarnya. Kondisi ini semakin diperparah dengan adanya gejala kesulitan melakukan hal-hal yang sebelumnya sangat mudah untuk dilakukan oleh mereka. Pada praktiknya, para penyandang afasia akan bersusah-payah dan sangat memerlukan banyak waktu untuk melakukan hal-hal yang sebelumnya sangat mudah mereka lakukan Kondisi ini semakin membuat mereka merasa kurang percaya diri dalam menjalani proses komunikasi dan sosialisasi dengan lingkungan sekitarnya.

Selanjutnya, Afasia sebagai gangguan berbahasa, telah menarik para ahli linguistik untuk mengkajinya. Perhatian para ahli linguistik terhadap afasiologi ini begitu besar.
Mereka mengharapkan bahwa dengan mempelajari afasia, dapat ditemukan keterangan untuk lebih memahami proses bahasa secara normal, polapola bahasa yang dihasilkan oleh para penyandang afasia, serta bagaimana berlang-sungnya proses berbahasa pada otak.

Rumah Sakit Pusat Otak Nasional (RSPON) Jakarta merupakan rumah sakit yang didirikan oleh pemerintah yang diharapkan dapat menjadi tempat pelayanan kesehatan otak dan saraf yang komprehensif. Keberadaannya yang begitu vital dalam kaitannya dengan permasalahan medis otak dan saraf, RSPON menjadi model dan percontohan dalam penanganan kasus-kasus neurologi di Indonesia.

Kompleksitas permasalahan medis di bidang otak dan saraf (neurologi) di Indonesia mengalami peningkatan dalam satu dekade terakhir. Kasus medis yang memiliki intensitas kejadian yang tinggi di bidang neurologi adalah strok. Dalam hubungannya dengan afasia, strok menjadi penyebab utama terjadinya afasia. Pada Riset Kesehatan Dasar Kementerian Kesehatan (2013), prevalensi penyandang strok mencapai $15,4 \%$. Kondisi ini menjadi penyebab kematian dan kecacatan utama di hampir seluruh rumah sakit di Indonesia.

Penyandang afasia broca memiliki problematika lingual yang begitu memperihatikan. Mereka memiliki masalah dalam meng-ungkapkan pikirannya melalui bahasa. Pada praktiknya, mereka tidak dapat menggunakan medium bahasa sebagaimana fungsinya. Dengan demikian, proses komunikasi antara 
penyandang afasia broca dengan orang-orang di sekitanya akan mengalami gangguan. Kondisi demikian akan bisa diatasi, salah satunya, dengan proses terapi wicara untuk mengembalikan kemampuan berbahasa penyandang afasia broca.

Dalam kaitannya dengan kompetensi berbahasa, proses terapi wicara akan menjadi menarik untuk dikaji, khususnya mengenai pola komunikasi antara terapis dan pasien. Oleh karena itu, dalam kajian linguistik, muncul satu kajian baru bernama komunikasi terapeutik.

Ada keunikan tersendiri dari pola komunikasi yang dijalin oleh terapis wicara dengan pasien penyandang afasia broca di Rumah Sakit Pusat Otak Nasional Jakarta. Pada prakitnya, penyandang afasia broca memiliki tata cara tutur yang berbeda dengan orang biasa dalam konteks komunikasi dengan terapis wicara. Satu di antara keunikan yang ada adalah tentang kompetensi komunikasi (CC) penyandang afasia broca.

Oleh karena itu, melalui penelitian ini, penulis mencoba untuk mengkaji komunikasi terapeutik dalam proses pemulihan kompetensi linguistic pasien afasia broca di Rumah Sakit Pusat Otak Nasional Jakarta. Hal ini dirasa perlu untuk segera diungkap sehingga penulis memformulasikan judul tulisan ini menjadi "Komunikasi Terapeutik dalam Proses Pemulihan Kompetensi Linguistik Pasien Penyandang Afasia Broca”.

\section{METODE}

Penelitian ini merupakan penelitian yang mendasarkan diri atas konsep case study. Penelitian ini dilakukan dengan menggunakan metode kualitatif-deskriptif dengan pendekatan studi kasus. Metode kualitatif dipilih dengan mempertimbangkan ciri-ciri dan sifat-sifat data sebagaimana adanya. Penentuan metode ini sangat akomodatif dengan jenis dan varian data yang akan dianalisis.

Penelitian ini dilakukan dengan mempertimbangkan dua pendekatan, yaitu pendekatan teoretis dan pendekatan metodologis. Secara teoretis, pendekatan yang digunakan di dalam penelitian ini adalah komunikasi terapeutik. Adapun secara metodologis, penelitian ini menggunakan metode kualitatif dengan pendekatan studi kasus. Secara kualitatif artinya data yang diteliti dan hasil analisisnya diperoleh dari rekaman, pengamatan, wawancara, atau bahan tertulis dan data ini tidak berbentuk angka (Djojosuroto dan Kinayati, 2001:17). Sementera pendekatan deskriptif mendasarkan pada fakta, yang secara empiris dan penutur-penuturnya, sehingga hasilnya berupa perian bahasa seperti apa adanya. Penggunaan metode deskriptif ini senada dengan apa yang dijelaskan Sudaryanto (2015:131143) bahwa data yang didapatkan adalah, shasil pengamatan penulis atanpamenilai salah atau benar suatu data.

Fuchran (1990) menjelaskan bahwa subjek dalam penelitian kualitatif, baik individu maupun kelompok, tidak dipersempit menjadi variabel yang terpisah, melainkan dipandang sebagai bagian utuh dari suatu kesatuan. Dalam penelitian jenis ini, subjek diamati secara mendalam - dalam pendekatan klinik 
genetik biasa disebut dengan pendekatan studi kasus. Dengan demikian, bisa kita pahami bahwa studi kasus merupakan bagian yang tidak terpisahkan dari metode kualitatif yang menjadikan objek penelitian diamati secara mendalam sehingga menghasilkan data empiris yang bersifat deskriptif.

Data penelitian ini berupa ekspresi verbal para penyandang afasia broca berbahasa Indonesia. Hal-hal yang akan dilakukan adalah pertama, studi pustaka, yaitu penelusuran terhadap penelitian terdahulu yang bersinggungan dengan topik ini. Hal ini perlu dilakukan, mengingat kajian-kajian tentang topik ini dengan berbagai sudut pandang telah dilakukan meskipun kuantitasnya masih relatif terbatas agar tidak terjadi tumpang tindih antara penelitian ini dengan penelitianpenelitian terdahulu, serta untuk memetakan posisi penelitian ini di antara penelitian-penelitian terdahulu. Setelah ditemukan beberapa penelitian terdahulu yang bersinggungan dengan penelitian ini, selanjutnya akan dilakukan pengkajian terhadap konsep yang mendukung konsep ini yang memfokuskan kepada permasalahan yang berhubungan dengan data lingual dan tujuan penelitian ini. Kedua, penyediaanesia dan D Setelah data didapatkan, tahap data, yaitu menggunakan kombinasi metode simak dan cakap dengan teknik dasar berupa teknik sadap dan teknik lanjutan berupa teknik catat dan rekam. Selanjutnya, penggunaan teknik interview (wawancara) tak terstruktur dan instrumen menjadi teknik lainnya dalam pengumpulan data di samping teknik elisitasi (pemancingan) (Sudaryanto, 2015).
Selain itu, teknik perekaman akan sering digunakan secara bersamaan dengan tujuan agar pada saat pengolahan, datanya masih dapat didengar kembali tuturan mereka.

Secara keseluruhan penelitian ini mengambil lokasi di Rumah Sakit Pusat Otak Nasional Jakarta. Sebanyak 3 (tiga) orang responden dijadikan sampel penelitian yang memenuhi kriteria inklusi (positif afasia broca berbahasa Indonesia, berjenis kelamin lelaki dan/atau perempuan, berusia 35 s.d. 75 tahun, menyatakan tidak berkeberatan disertakan dalam penelitian, dan dapat berbahasa Indonesia). Penentuan sampel dilakukan dengan teknik purposif atau emergent 'mencuat' (Alwasilah, 2003:72) dengan rasio yang cukup proposional.

Pemerolehan data dilakukan di lokasi penelitian dengan dua cara, yaitu wawancara yang terpandu dengan menggunakan instrumen penelitian dan pengamatan proses terapi wicara yang sedang berlangsung antara terapis wicara dengan penyandang afasia broca. Konversasi yang dihasilakna dari wawancara dan menggunakan alat perekam dengan durasi perekaman kurang lebih 50 s.d. 60 menit.astra

selanjutnya adalah transkripsi dan pengelompokkan data menjadi data pertama dan data kedua. Yang dimaksud dengan data pertama adalah data yang dipilih berdasarkan respon dan jawaban responden atas pertanyaan pengarah yang sudah disiapkan. Adapun data kedua adalah data yang diambil dari respon dan jawaban responden atas pertanyaanproses terapi wicara tersebut, direkam 
pertanyaan bebas dan acak yang diajukan oleh penulis secara langsung di luar dari data pertanyaan yang sudah disediakan pada daftar pertanyaan pengarah. Data yang dihasilkan dari bantuan penulis dengan menyebutkan huruf, suku awal kata yang dimaksud, memberi contoh pengucapan kata/kalimat, dan pemberitahuan ciri-ciri kata yang dimaksud - juga akan dimasukkan ke dalam jenis data kedua. Selain itu, data yang dihasilkan dari proses berlangsungnya terapi wicara antara terapis wicara dengan penyandang afasia, akan dimasukkan juga ke dalam jenis data kedua.

Penganalisisan data dilakukan dengan metode kualitatif, artinya bahwa kegiatan analisis yang dilakukan berkaitan dengan pola-pola yang umum pada wujud dan perilaku data yang ada yang dipengaruhi dan yang hadir bersama dengan kontekskonteksnya (Asher 1994 dalam Arimi 1998:27). Data yang sudah dianalisis disajikan secara deskriptif, yaitu perumusan dan pengungkapan hasil analisis dengan menggunakan katakata atau kalimat-kalimat.

Selanjutnya, data yang terkumpul juga dianalisis dengan menggunakan kombinasi metode padan dan distribusional (Djajasudarma, 2010) Metode padan diartikan sebagai metode yang menjadikan unsur luar bahasa sebagai alat penentunya, terlepas dan tidak menjadi bagian dari bahasa yang bersangkutan (Sudaryanto, 2015). Pada penelitian ini, digunakan juga metode distribusional, yaitu metode yang menganalisis data dengan cara menghubungkan antargejala bahasa. Teknik bagi unsur langsung dijadikan sebagai teknik dasar dengan cara membagi satuan lingual data menjadi beberapa bagian.

\section{HASIL DAN PEMBAHASAN}

Seperti yang sudah dikemukakan pada bagian-bagian sebelumnya, penyandang afasia broca memiliki problematika lingual yang begitu memperihatikan. Mereka memiliki masalah dalam mengungkapkan pikirannya melalui bahasa. Pada praktiknya, mereka tidak dapat menggunakan medium bahasa sebagaimana fungsinya. Dengan demikian, proses komunikasi antara penyandang afasia broca dengan orang-orang di sekitanya akan mengalami gangguan. Kondisi demikian akan bisa diatasi, salah satunya, dengan proses terapi wicara untuk mengembalikan kemampuan berbahasa penyandang afasia broca.

Dalam kaitannya dengan kompetensi berbahasa, proses terapi wicara akan menjadi menarik untuk dikaji, khususnya mengenai pola komunikasi antara terapis dan pasien. Oleh karena itu, dalam kajian linguistik, muncul satu kajian baru bernama komunikasi terapeutik.

Ada keunikan tersendiri dari pola komunikasi yang dijalin oleh terapis wicara dengan pasien penyandang afasia brocacdi Rumah Sakit Pusat Otak ${ }^{\text {eral }}$ Nasional Jakarta. Pada prakitnya, penyandang afasia broca memiliki tata cara tutur yang berbeda dengan orang biasa dalam konteks komunikasi dengan terapis wicara. Satu di antara keunikan yang ada adalah tentang kompetensi komunikasi (CC) penyandang afasia broca.

Kompetensi komunikasi terapis wicara pada saat komunikasi terapeutik dengan penyandang afasia 
broca menjadi aspek penentu bagi keberlangsungan komunikasi antara terapis wicara dengan klien afasia broca. Hal ini disebabkan oleh kondisi penyandang afasia broca yang memiliki kendala komunikasi dalam memproduksi bahawa, tentu akan mengalami gangguan komunikasi dan mereka akan merasa kesulitan untuk memproduksi bahasanya. Terapis wicara sebagai orang "normal" tentu memiliki tanggung jawab moral untuk membantu klien dalam pemerolehan bahasanya kembali.

\section{Komunikasi Terapeutik dalam} Proses Pemulihan Kompetensi Linguistik Pasien Afasia Broca

\section{(1) Alih Gaya (Style Shifting)}

Dalam konteks kompetensi berbahasa, terapis wicara memiliki kemampuan mengetahui beragam pilihan kata. Kompetensi demikian tentu menjadi hal yang niscaya ada pada seorang terapis wicara, khususnya dalam konteks komunikasi terapeutik dengan klien penyandang afasia broca. Dengan kompetensi berbahasa tersebut, seorang terapis wicara akan dengan mudah memilih kata yang paling tepat dan paling mudah dipahami oleh penyandang afasia broca. Pasalnya, penyandang afasia broca notabene tidak memiliki kompetensi berbahasa yang bagus, tentu akan mengalami kesulitan untuk memahami kata-kata tertentu. Dengan memiliki pilihan kata yang berlimpah, seorang terapis wicara akan dengan mudah mengganti kata yang sulit dipahami dengan kata lain (yang semakna) yang lebih mudah untuk dipahami oleh klien penyandang afasia broca.
Dari proses komunikasi terapeutik yang ada di Rumah Sakit Pusat Otak Nasional antara terapis wicara dengan klien penyandang afasia broca, terdapat beberapa gejala lingual yang patut untuk dikemukakan pada bagian ini. Gejala-gejala tersebut adalah adanya alih gaya (style shifting)) dan adanya pemberian feedback positif dari terapis wicara kepada klien penyandang afasia broca.

Adanya keterbatasan kompetensi berbahasa penyandang afasia broca, tentu disadari oleh terapis wicara. Hal ini tampak dari adanya strategi komunikasi yang dibangun oleh terapis wicara dengan memproduksi kalimat-kalimat sederhana agar dapat dipahami dengan mudah oleh klien penyandang afasia broca. Tentu pemilihan strategi ini diperuntukkan agar proses komunikasi antara terapis wicara dengan penyandang afasia brica tersebut tetap berjalan dengan lancara.

Alih gaya (style shifting) sering dilakukan oleh terapis wicara jika didapai klien penyandang afasia broca tidak mengerti/memahami apa yang diucapkan atau diinstruksikan. Kondisi lainnya adalah ketika klien penyandang afasia broca tidak merespon apa-apa yang diinstruksikaneroleh terapis wicara, sebagaimana yang diharapkan. Untuk menyiasati hal tersebut, seorang terapis wicara langsung mengubah strateginya dengan alih gaya. Alih gaya di sini dipahami sebagai perubahan gaya komunikasi lingual, dari gaya formal ke gaya nonformal. Perhatikan contoh data berikut ini.

(1) Terapis : Iya, tangan. Tapi pake alat apa? 


$\begin{array}{ll}\text { Pasien } & \text { : Eh... mangkok. } \\ \text { Terapis } & \text { : Bukan. } \\ \text { Pasien } & \text { : Ge... gelas. } \\ \text { Terapis } & \text { : Wiiih... Hebaaat. } \\ \text { Percakapan } & \text { tersebut seharusnya } \\ \text { perti berikut, } & \text { jika tanpa dilakukan } \\ \text { gaya. } & \\ \text { Terapis } & : \text { Iya, tangan. Tetapi, } \\ & \text { memakai alat apa? } \\ \text { Pasien } & : \text { Eh... mangkok. } \\ \text { Terapis } & : \text { Bukan. } \\ \text { Pasien } & : \text { Ge... gelas. } \\ \text { Terapis } & : \text { Hebat, Anda } \\ & \text { Berhasil } \\ & \text { menyebutkannya! }\end{array}$

Alih gaya dilakukan oleh seorang terapis wicara secara spontan tanpa dimaksudkan untuk memperjelas sesuatu yang tidak dipahami oleh klien penyandang afasia broca. Alih gaya semacam ini wajar terjadi dalam suatu situasi percakapan seperti yang diungkapkan SavilleTroike (2003:55) bahwa "Alih kode bisa saja tidak disadari, dan pada kenyataannya alih code itu sendiri mungkin menjadi berarti dalam mengekspresikan sebuah kedekatan atau hubungan yang lebih informal sebagai isi rujukan atau penggunaan bentuk bahasa yang khusus".

\section{(2) Pemberian Feedback Positif}

Gejala lainnya yang tampak pada komunikasi terapeutik di Rumah Sakit Pusat Otak Nasional antara terapis wicara dengan klien penyandang afasia broca adalah dalam konteks keterampilan berinteraksi. Seorang terapis wicara untuk klien afasia broca ini memiliki keterampilan dalam memberikan feedback positif. Feedback positif tersebut terejawantahkan dalam bentuk apresiasi terhadap keber- hasilan pasien dalam menyebutkan sesuatu. Terapis wicara mengetahui bagaimana memotivasi dan memberikan nilai positif kepada klien dengan memberikan respon-respon positif di setiap keberhasilan klien menyebutkan sesuatu.

Bentuk-bentuk feedback positif yang dimaksud adalah salah satunya dengan sering menyebutkan kata-kata seru, seperti Oke, bagus!, Hebaat, He eh bener, Ini langsung bisa pak. Hebat, dan sebagainya. Ekspresi nonlinguistik juga sering digunakan terapis wicara untuk memberikan feedback positif kepada klien penyandang afasia broca, seperti tepuk tangan, dan gesture yang positif lainnya.

Selain dengan memberikan pujian kepada klien penyandang afasia broca, terapis wicara juga kerap kali memberikan motivasi dengan berupa memunculkan modalitas yang telah dikuasai oleh klien, di antaranya dengan memohon kepada klien untuk menyebutkan ulang, menyebutkan sesuatu yang sudah dilihat, mengucapkan sesuatu yang berurutan, yang notabene sudah familiar dengan klien. Pola komunikasi tersebut dapat dilihat pada percakapan berikut ini.
(2) Terapistro

\section{DPasien}

Terapis

Pasien

Terapis

Pasien

Terapis

Pasien

Terapis pesayap!
: Yang di udara?

: Bentang keluar... eh, pelayang.

: Pesa?

: Pesayang, eh...

:Pe-sa-wat!

: Pesayang, eh, pesawat.

\section{:Diulang!}

: Pesayang, eh...

:Pesawat! 


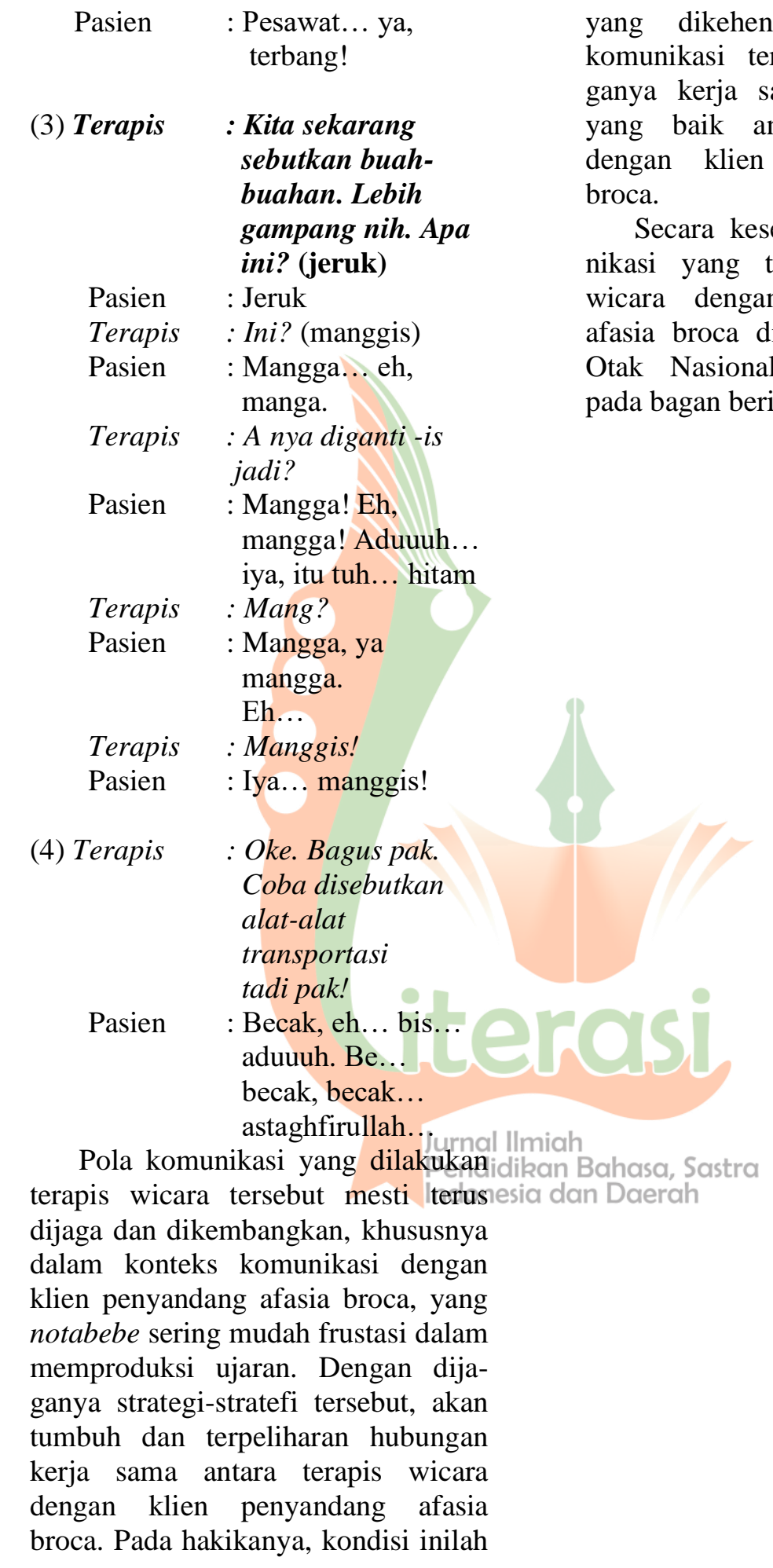

yang dikehendaki dalam proses komunikasi terapeutik, yaitu terjaganya kerja sama dan komunikasi yang baik antara terapis wicara dengan klien penyandang afasia broca. nikasi yang terjadi antara terapis wicara dengan klien penyandang afasia broca di Rumah Sakit Pusat Otak Nasional Jakarta, tergambar pada bagan berikut ini. 


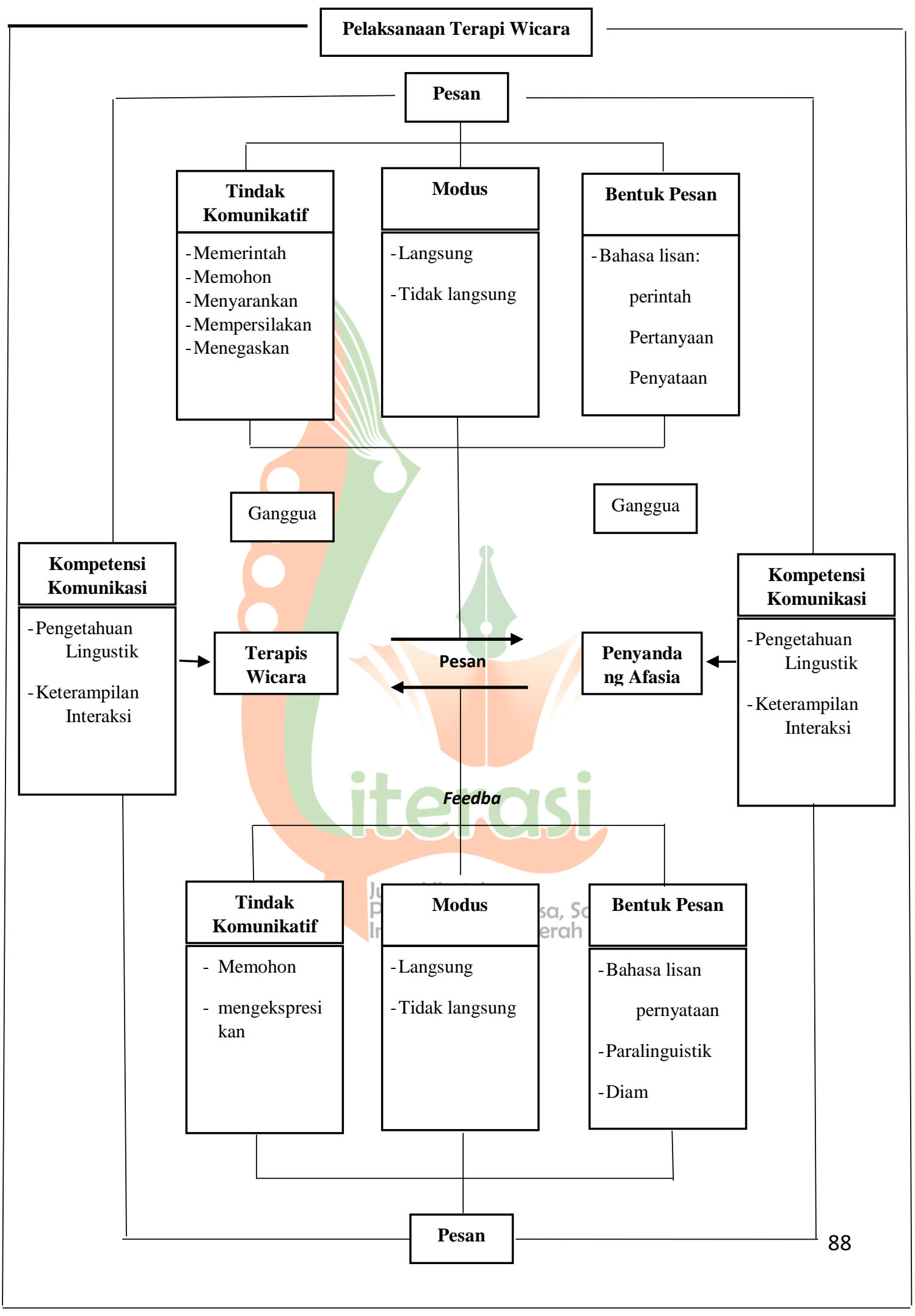




\section{PENUTUP}

\section{Simpulan}

Penyandang afasia broca memiliki problematika lingual yang begitu memperihatikan. Mereka memiliki masalah dalam mengung-kapkan pikirannya melalui bahasa. Pada praktiknya, mereka tidak dapat menggunakan medium bahasa sebagaimana fungsinya. Dengan demikian, proses komunikasi antara penyandang afasia broca dengan orang-orang di sekitanya akan mengalami gangguan. Kondisi demikian akan bisa diatasi, salah satunya, dengan proses terapi wicara untuk mengembalikan kemampuan berbahasa penyandang afasia broca.

Ada keunikan tersendiri dari pola komunikasi yang dijalin oleh terapis wicara dengan pasien penyandang afasia broca di Rumah Sakit Pusat Otak Nasional Jakarta. Pada prakitnya, penyandang afasia broca memiliki tata cara tutur yang berbeda dengan orang biasa dalam konteks komunikasi dengan terapis wicara. Satu di antara keunikan yang ada adalah tentang kompetensi komunikasi (CC) penyandang afasia broca.

Berdasarkan proses komunikasi terapeutik yang ada di Rumah Sakit Pusat Otak Nasional antara terapis wicara dengan klien penyandang afasia broca, terdapat beberapa gejala lingual yakni adanya alih gaya (style shifting)) dan adanya pemberian feedback positif dari terapis wicara kepada klien penyandang afasia broca.

\section{Saran}

Penelitian ini menjadi satu di antara beberapa aspek yang dapat diangkat dari fenomena lingual para penutur afasia. Penelitian-penelitian serupa dengan subjek yang lebih banyak, perlu dilakukan dengan memerlukan waktu yang lumayan lama. Diharapkan dengan ketersediaan waktu yang cukup memadai, dapat menghasilkan output dan oiutcome penelitian yang komprehensif

\section{DAFTAR PUSTAKA}

Alwasilah, A. Chaedar. 2003. Pokoknya Kualitatif: Dasardasar Merancang dan Melakukan Penelitian Kualitatif. Cet. II. Pustaka Jaya, Jakarta.

Arimi, Sailal. 1998. "Basa-Basi dalam Masyarakat Bahasa Indonesia”. Tesis Program Pascasarjana Universitas Gadjah Mada, Yogyakarta.

Association Internationale Aphasie. 2011. Afasia Broca. Tersedia: http://www.afasie.nl/aphasia/pdf/ 26/brochure1.pdf. Diakses pada 9 Maret 2019.

Djojosuroto, K. dan M.L.A. Sumaryati. 2004. Prinsip-Prinsip Dasar dalam Penelitian Bahasa dan Sastra. Bandung: Nuansa.

Fuchran, Arief. 1990. Pengantar Metode Penelitian Kualitatif. Surabaya: PUN.

Kusumoutro; $; \quad$ Sidiarto. 1999. Asesmen Afasia. Neurona Vol. 16, 1-2, 21-25.

Kridalaksana, Harimurti. 1993. "Linguistik dan Cacat Bahasa". Makalah Seminar Sehari Neurolinguistik, Kampus FSUI, Depok, 1 Mei.

Sastra, Gusdi. 2011. Neurolinguistik Suatu Pengantar. Bandung: Alfabeta. 
Sudaryanto. 2015. Metode Linguistik

ke Arah Memahami Metode

Linguistik. Yogyakarta: Gadjah Mada University Press.

Yunus, Syafruddin. 1999. Anatomi

dan Sindromologi Afasia.

Neurona 16 (1-2) 1-10.

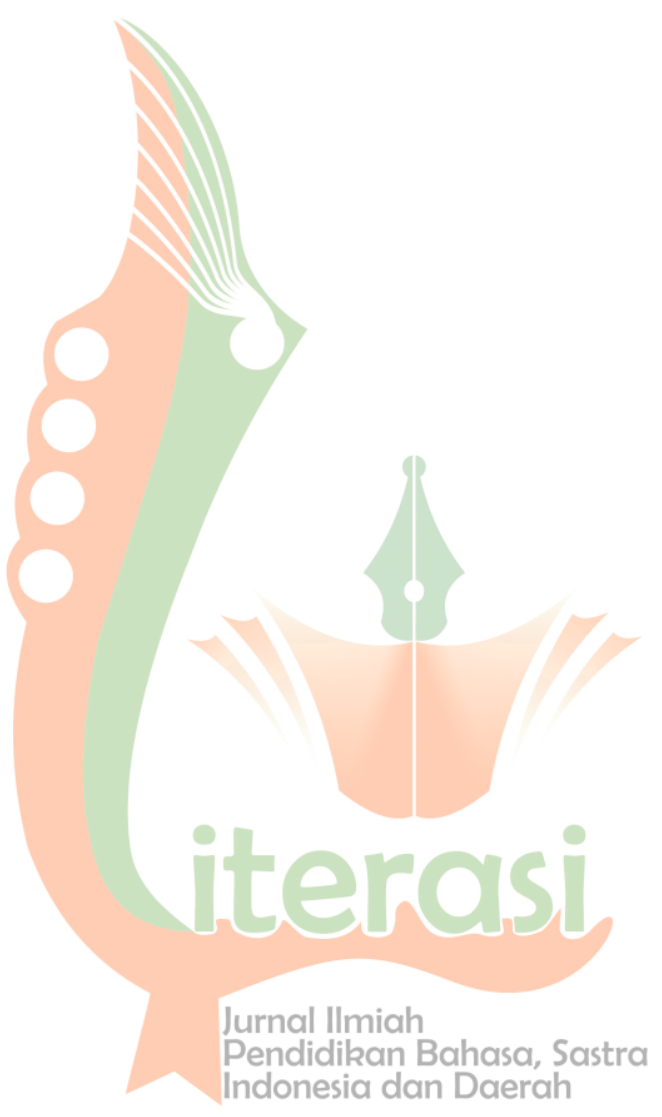

